January 2009

\title{
Lost in (Doctrinal) Translation: The Misleading Retelling of the Supreme Court's Antitrust Decisions on Restraints of Trade
}

Peter C. Carstensen

\section{Recommended Citation}

Peter C. Carstensen, Lost in (Doctrinal) Translation: The Misleading Retelling of the Supreme Court's Antitrust Decisions on Restraints of Trade, 62 SMU L. REV. 525 (2009)

https://scholar.smu.edu/smulr/vol62/iss2/5

This Article is brought to you for free and open access by the Law Journals at SMU Scholar. It has been accepted for inclusion in SMU Law Review by an authorized administrator of SMU Scholar. For more information, please visit http://digitalrepository.smu.edu. 


\title{
LOST IN (DOCTRINAL) TRANSLATION: The Misleading Retelling of the Supreme Court's Antitrust Decisions on Restraints of Trade
}

\author{
Peter C. Carstensen*
}

$\mathrm{F}$

TOR decades, the most popular quotation from literature in antitrust briefs came from the follow-up to Alice in Wonderland, Through the Looking-Glass: "When I use a word . . . it means just what I choose it to mean. . . . When I make a word do a lot of work like that, ... I always pay it extra."1 This is because the "rule of reason" as well as the "per se" rule are ambiguous concepts. Thus, United States $v$. Topco stands for the proposition that all horizontal agreements allocating customers or territories are "per se violation[s]"2 and for the proposition that restraints among competitors regarding territories and customers can be reasonable and lawful. ${ }^{3}$

A number of reasons explain the persistence of this doctrinal ambiguity. Among them is the common law tradition of building on prior case decisions. Those decisions provided a vocabulary to describe outcomes, but over time that vocabulary has become disconnected from the underlying factual and policy analyses that motivate the results. ${ }^{4}$ Another com-

* George C. Young-Bascom Professor of Law, University of Wisconsin. This Article builds in part on the work of my students in the antitrust law and economics seminar over a number of years. I am also indebted to Nadia Elnagdy for research and editorial assistance.

1. Lewis Carroll, Through the Looking-Glass: And What Alice Found THERE 124-25 (Macmillan \& Co. 1872).

2. United States v. Topco Assocs., Inc., 405 U.S. 596, 597 (1972).

3. United States v. Topco Assocs., Inc., 414 U.S. 801, 801 (1973) (upholding by an 8-1 vote a modified decree, United States v. Topco, Assocs., Inc., 1973-1 Trade Cases 91 74,485, at *5 (N.D. Ill. 1973), in the Topco case that expressly authorized the use of "pass-over" payments if a Topco member entered another member's territory and that resulted in economic losses to the incumbent with respect to its investments in the Topco brands). For a fuller analysis of the case, see generally Peter C. Carstensen \& Harry First, Rambling Through Economic Theory: Topco's Closer Look, in ANTITRUST STORIES (Dan Crane \& Eleanor Fox eds., 2007).

4. I have elsewhere suggested that there are several distinct lines of analysis that exist for determining the substantive results in antitrust cases. Peter C. Carstensen \& Richard F. Dahlson, Vertical Restraints in Beer Distribution: A Study of the Business Justifications for and Legal Analysis of Restricting Competition, 1986 WIs. L. Rev. 1, at 63-67. One persistent problem is that many scholars try to weave the stated doctrines of the cases into a single internally consistent pattern. Such a pattern must be extremely flexible because it necessarily must accommodate inconsistent approaches. While the outcomes in the cases may be largely consistent, the reasoning is not. There are, at least, four discernable con- 
ponent is the way prior decisions are told and retold by judges, commentators, and advocates. ${ }^{5}$ This can and has resulted in a distorted doctrinal history. These distortions then motivated purported reversals of badly decided cases ${ }^{6}$ or judicial reliance on misconceptions of the cases in order to ignore important insights embedded in the decisions.

I have spent a part of my scholarly career looking at the history of leading cases to better understand the legal and factual underpinnings of these cases as well as the ways in which the lawyers sought to explain and advocate their positions. The results include an effort to contribute a better understanding of why, using ancillary restraint analysis in the tradition of Taft and early Bork, the result in the Chicago Board of Trade ${ }^{7}$ case is entirely legitimate. ${ }^{8}$ In collaboration with others, I have revisited $T o p c o^{9}$ and Khan. ${ }^{10}$ My goals include both clarifying the historical record with respect to these cases and providing a counterpoint to the misleading descriptions and characterizations of these cases that, in some degree, affect contemporary interpretation of antitrust law.

This Article examines four, interrelated constellations of foundational antitrust cases concerning the analysis of restraints of trade that I believe have not been well understood by courts and commentators. The historical contention is that, at its origins, antitrust caselaw focused primarily on the function of restraints. The contemporary policy inference is that returning to this fundamental conception would strengthen and clarify antitrust law. I will start with the pre-1911 Supreme Court antitrust case law. The thesis is that, when these cases are examined in light of their facts

tending approaches to deciding the merits of antitrust cases. In addition to the three suggested in the article above, id. at 63, Professors Gavil, Baker, and Kovasic have advanced a description based on a dichotomy they discern between "collusion" and "exclusion." See generally Andrew I. Gavil et al., Antitrust Law in Perspective: Cases, Concepts and Problems in Competition Policy ( $2 \mathrm{~d}$ ed. 2008). This Article is not the place, however, to elaborate on these contending frameworks.

5. An example is what appears to have been an aside in the Container Corporation case that took on a life of its own. See United States v. Container Corp. of Am., 393 U.S. 333 (1969). The Court distinguished an exchange of information that had not supported the inference of an anticompetitive underlying price fixing agreement by referring to the "controlling circumstance[s]" that had justified a similar exchange in the Cement Manufacturers' Protective Ass'n v. United States, 268 U.S. 588 (1925). Container Corp. of Am., 393 U.S. at 335. There followed a series of lower court cases in which parties to information exchange sought to parse the "controlling circumstances" phrase to justify their conduct. See, e.g., United States v. U.S. Gypsum Co., 550 F.2d 115, 123 (3d Cir. 1977). (2007).

6. See, e.g., Leegin Creative Leather Prods. v. PSKS, Inc., 127 S. Ct. 2705, 2725

7. Chicago Bd. of Trade v. United States, 246 U.S. 231 (1918).

8. See generally Peter C. Carstensen, The Content of the Hollow Core of Antitrust: The Chicago Board of Trade Case and the Meaning of the "Rule of Reason" in Restraint of Trade Analysis, 15 Res. L. \& ECON. 1 (1992).

9. See Carstensen \& First, supra note 3.

10. State Oil v. Khan, 522 U.S. 3 (1997); see generally Peter C. Carstensen \& David Hart, Kahning the Court: How the Antitrust Establishment Obtained an Advisory Opinion Legalizing "Maximum" Price Fixing, 34 U. Tol. L. Rev. 241 (2003) (describing the actual context in which the maximum prices were set: the gas station had a large number of nearby competitors thus falsifying the theories of the Court that it had monopoly market power). 
and the Court's response, the doctrine in this period was internally consistent and not the illogical literal-formalism that some casebook editors assert existed. ${ }^{11}$ Northern Securities ${ }^{12}$ is a central case in this period from the perspective of those who claim that the Court had a formalist approach which the 1911 Standard Oil ${ }^{13}$ and American Tobacco ${ }^{14}$ decisions reversed. Hence, it is important to look closely at the actual issues at stake in Northern Securities and the contending positions of the justices. The central result of this review is that the primary dispute within the Court was over the scope of antitrust law's jurisdiction under prevailing notions of inter-state and intra-state commerce. Indeed, all the justices agreed that Northern Securities's acquisition of control of the only two competing railroads in a vast region of the northern half of the United States was likely to result in anticompetitive effects. Secondarily, the justices disagreed over the definition of "restraint of trade," with the dissent again taking a backward looking, narrow perspective that modern antitrust law has repudiated. The upshot of this historical review is that a majority of the Court adhered to a consistent and rational functional approach to restraints of trade.

Second, contemporary analysis of the possible meanings of the rule of reason can benefit from a more focused juxtaposition of the three great decisions of 1911, Standard Oil, American Tobacco, and Dr. Miles. ${ }^{15}$ The explication of that "rule" starts essentially with the Standard Oil and American Tobacco decisions. In fact, Chief Justice White, the author of Standard Oil and American Tobacco, shifted his position concerning the rule of reason from his earlier position in the Joint-Traffic and Northern Securities cases. This demonstrable shift, especially in light of the explicit functional analysis in Dr. Miles, supports the conclusion that, at its origin, the rule of reason may have had a more focused, functional meaning than is usually ascribed to it.

Third, drawing on that same trinity of 1911 decisions, it is possible to show that Justice Hughes's opinion in Dr. Miles is not inconsistent in its analytic framework from one plausible interpretation of Leegin. ${ }^{16}$ Indeed, had the Leegin Court simply declared that it had returned to the framework employed in $D r$. Miles, the determination of reasonableness of resale price fixing would have been much advanced over the ambiguous and unstructured analysis that the Court suggested in Leegin. Reading the Leegin decision in context with California Dental Association, ${ }^{17}$ might well suggest that the Court, ignoring more than a century of experience, has now embraced the original conception of the rule of reason as

11. Robert Pitofsky et al., Trade Regulation: Cases and Materials 55-56 (5th ed. 2003).

12. N. Sec. Co. v. United States, 193 U.S. 197 (1904).

13. Standard Oil Co. of N.J. v. United States, 221 U.S. 1 (1911).

14. United States v. Am. Tobacco Co., 221 U.S. 106 (1911).

15. Dr. Miles Med. Co. v. John D. Park \& Sons Co., 220 U.S. 373 (1911).

16. Leegin Creative Leather Prods., Inc. v. PSKS, Inc., 127 S. Ct. 2705 (2007).

17. Cal. Dental Ass'n v. FTC, 526 U.S. 756 (1999). 
set forth by Justice White in Trans-Missouri. ${ }^{18}$ If this is true, such a reversion would be unfortunate indeed.

Fourth, the Chicago Board of Trade ${ }^{19}$ and Appalachian Coals ${ }^{20}$ decisions merit one more review to show that they are not actually the openended "good thing" or "bad thing" inquiries that are commonly ascribed to them. The thesis advanced here is that each case involved restraints that were at least arguably (Appalachian Coals) or demonstrably (Chicago Board of Trade) ancillary to primary, legitimate joint-productive ventures among the parties to the restraints. Thus, these decisions do not provide a basis for the kind of open-ended weighing of the subjective merits of restraints found in such recent decisions as California Dental, Khan, and Leegin.

The overall conclusion is that there is a more consistent and principled functional framework for the analysis of restraints of trade in these foundational antitrust decisions from the Supreme Court if one looks more carefully at what was before the Court and what it actually said and did in each of the cases.

\section{THE EARLY YEARS}

Prior to Northern Securities, the Supreme Court decided six restraint of trade cases $^{21}$ as well as one merger-to-monopoly case. ${ }^{22}$ The Government prevailed in three of these seven decisions. ${ }^{23}$ A private plaintiff won one case and the Government lost three cases-two involving re-

18. United States v. Trans-Missouri Freight Ass'n, 166 U.S. 290 (1897).

19. Bd. of Trade v. United States, 246 U.S. 231 (1918).

20. Appalachian Coals, Inc. v. United States, 288 U.S. 344 (1933).

21. W.W. Montague \& Co. v. Lowry, 193 U.S. 38 (1904); Addyston Pipe \& Steel Co. v. United States, 175 U.S. 211 (1899) aff g as modified, 85 F. 271 (6th Cir. 1898); Anderson v. United States, 171 U.S. 604 (1898); Hopkins v. United States, 171 U.S. 578 (1898); United States v. Joint-Traffic Ass'n, 171 U.S. 505 (1898); United States v. Trans-Missouri Freight Ass'n., 166 U.S. 290 (1897). In re Debs, 158 U.S. 564 (1895), is sometimes understood to involve an application of antitrust law to labor disputes, but the Supreme Court in affirming the injunction against the strike stated: "We enter into no examination of the [Sherman Act] . . . upon which the circuit court relied mainly to sustain its jurisdiction. It must not be understood from this that we dissent from the conclusions of that court in reference to the scope of the act, but simply that we prefer to rest our judgment on the broader ground which has been discussed in this opinion, believing it of importance that the principles underlying it should be fully stated and affirmed." Id. at 600 . Subsequent development of antitrust law's application to labor disputes is not entirely inconsistent with the historical framework suggested for business cases. The Court consistently objected to multi-employer agreements and ones involving third parties (naked restraints of competition in business terms) but found various ways to avoid challenging disputes between an employer and its own employees (an internal negotiation of ancillary restraints akin to those upheld in Texaco Inc. v. Dagher, 547 U.S. 1 (2006)). See generally Daniel R. ERnST, Lawyers against Labor: From Individual Rights to Corporate Liberalism (1995).

22. United States v. E. C. Knight Co., 156 U.S. 1 (1895).

23. Addyston Pipe, 175 U.S. at 248; Join-Traffic, 171 U.S. at 577-578; Trans-Missouri, 166 U.S. at $342-43$. 
straints and one involving a merger. ${ }^{24}$ Thus, at the outset, it seems quite a stretch to regard the Supreme Court of the 1890s as compulsively antibusiness. Indeed, if one looks outside antitrust law, it is apparent that the Court was in fact quite protective of business interests in a great variety of ways. ${ }^{25}$

The six section 1 decisions in that period show a clear line of demarcation: the four finding violations all involved blatant cartels that allocated markets and exploited customers, while the other two cases upholding restraints involved restraints incident to the creation of joint ventures or efforts to make joint ventures more efficient and effective collective enterprises. The factual stories are thus quite distinct.

In both Trans-Missouri ${ }^{26}$ and Joint-Traffic, ${ }^{27}$ the Court rejected cartels involving railroads operating west of the Mississippi River that had entered into agreements that sought to stabilize competition by setting rates and allocating markets. Ultimately, rate and service regulation through the Interstate Commerce Commission (ICC) came to provide the kind of stability that, as some have argued, railroads needed because of their economic structure of low marginal but high fixed costs and the existence of substantial excess capacity that was both durable and activity specific. ${ }^{28}$

Addyston Pipe involved a cartel among sewer pipe manufacturers in the southeastern part of the United States who had created an ingenious and effective market allocation scheme. ${ }^{29}$ They agreed on high prices for their product. Demand was very price inelastic, and the remote capacity of non-conspirators was the only effective constraint. ${ }^{30}$ The conspirators held internal auctions to determine which one would be assigned the winning bid and provide the pipe. ${ }^{31}$ The rest of the cartel provided courtesy bids. ${ }^{32}$ The difference between the internal bid and the bid to the buyer was then shared among the conspirators. The defendants argued that they needed a cartel to avoid "destructive competition"; moreover, they claimed that the prices they imposed were "reasonable" and that their

24. Montague \& Co., 193 U.S. at 48 (private plaintiff); Anderson, 171 U.S. at 620 (restraint); Hopkins, 171 U.S. at 603-04 (restraint); E.C. Knight Co., 156 U.S. at 17-18 (merger).

25. See, e.g., Smyth v. Ames, 171 U.S. 361, 365 (1898) (imposing strict constraints on state efforts to regulate prices of utilities). See generally Herbert HovenKaMP, ENTERPRISE AND AMERICAN LAW 1836-1937 (1991).

26. Trans-Missouri, 166 U.S. at 298-99, 303, 341-42.

27. Joint-Traffic, 171 U.S. at 506, 577.

28. Hovenkamp makes this point well in several chapters of his book. See HovenKAMP, supra note 25 , at 131-70. As to whether this served the public interest or only the private interests of the parties, there is a long standing and vigorous debate among historians. See, e.g., Gabriel Kolko, Railroads and Regulation 1877-1916 (1965).

29. United States v. Addyston Pipe \& Steel Co., 85 F. 271, 273-77 (6th Cir. 1898) aff d as modified, 175 U.S. 211 (1899).

30. Manifestly, sewer pipe, which is heavy and not very valuable on a per pound basis, faced very high shipping costs relative to its market price. This in turn limited the capacity of the non-conspirators to compete in what the cartel called "pay territory." Addyston Pipe, 85 F. at 274.

31. Id. at 274 .

32. Id. at 275 . 
restraints covered only a limited territory. ${ }^{33}$ Hence, their agreement should be lawful. This aspect of the case was the focus of Judge Taft's brilliant opinion for the court of appeals, joined by Justice Harlan and Judge Lurton, both present or future Supreme Court justices. ${ }^{34}$ Judge Taft articulated the naked-ancillary functional concept. ${ }^{35}$ Rejecting a substantial part of contemporary restraint of trade decisions, as having "set sail on the sea of doubt," 36 Judge Taft asserted that all naked restraints ("direct restraints" in the terms Justice Peckham used) were illegal and that ancillary restraints should be tested against a set of judicially administrable criteria: 1) the existence of a primary transaction or venture involving the parties, 2) the need to protect some legitimate interest in that transaction from opportunistic or other transaction-specific risks or needs, 3) the adopted restraint being reasonably related to the risk/ need of the transaction, and 4) the restraint being no more restrictive than was reasonably necessary to accomplish its primary goal of protecting the transaction or venture from the risk or need that justified the restraint. ${ }^{37}$

But the centerpiece of the defendants' argument to the Supreme Court was the claim that their cartel did not affect interstate commerce, as it involved only a general agreement not to compete and not a specific agreement with respect to any particular interstate transaction. ${ }^{38}$ The concept of interstate commerce was a narrow one in this period and focused largely on the physical movement of tangible goods from one state to another. ${ }^{39}$ Nevertheless, the Supreme Court unanimously rejected the interstate commerce argument because the parties had in fact agreed on how to allocate business that was to move in a physical sense among the states. $^{40}$ It did, however, modify the decree to allow collusion over prices within any one state in which the colluding parties operated. ${ }^{41}$

Finally, the Montague case, decided the same term as Northern Securities, involved an agreement among retailers of fireplace mantels to boycott any supplier that sold on similar terms to anyone not a member of the cartel. ${ }^{42}$ Thus, the cartel used its buying power to coerce producers

33. These arguments are more clearly stated in the Supreme Court opinion. See $A d$ dyston Pipe, 175 U.S. at 214, 225. Indeed, George Bittlingmayer has argued that the cartel was a necessary means to protect the industry from destructive competition arising from its economic characteristics. See generally George Bittlingmayer, Decreasing Average Cost and Competition: A New Look at the Addyston Pipe Case, 25 J.L. \& EcoN. 201 (1982).

34. Addyston Pipe, 85 F. at 279.

35. Id. at 279-292.

36. Id. at 284.

37. Id. at 287.

38. Addyston Pipe, 175 U.S. at 227. This is a classic example of how defendants in antitrust cases often avoid any real attempt to justify their conduct on its merits, but rather claim that the law does not apply. Not surprisingly, the Court rejected this sophistic argument. See id. at 240-41.

39. See, e.g., Paul v. Virginia, 75 U.S. 168, 183 (1868) (stating that insurance is not in interstate commerce because no commodity crosses a state line).

40. Addyston Pipe, 175 U.S. at 227-30, 240-41.

41. Id. at 247-48.

42. W. W. Montague \& Co. v. Lowry, 193 U.S. 38, $44-45$ (1904). 
into giving the cartel's members favorable terms and used that same power to create a barrier to entry that insulated the cartel's monopoly prices from local competition. This was a private action and, like Addyston Pipe, directly affected the interstate sale of the products involved..$^{43}$ Justice Peckham once again wrote the opinion.

In short, these four cases all involved what even today would be held to be per se illegal restraints of trade. They are consistent in their rejection of such conduct, regardless of the excuses or justifications that the parties might offer.

The contrasting cases, Hopkins and Anderson, both involved the Kansas City stockyards and efforts by groups of competitors to create joint enterprises that would provide essential inputs to their services so that they could operate more efficiently. ${ }^{44}$ Hopkins involved "yard-traders" who bought or sold cattle on behalf of others in the stockyard itself.45 Anderson involved a group of merchants who bought cattle at locations away from the stockyards and brought them to the yards for sales. ${ }^{46}$ These traders were often agents for third parties and needed to have counter-parties with whom to trade. In economic terms, they served narrow and limited functions. To create a more complete venture, they needed to have an infra-structure that would facilitate and support their individual activities. ${ }^{47}$ Such joint ventures could create significant economies in the individual firm's business because agreeing upon standards for trading, methods of resolving disputes, and necessary support services allowed each trader to lower its costs of doing business. At the same time, such joint ventures faced a variety of risks of opportunistic behavior by participants including individual interests in market manipulation contrary to the collective interest of the group and free-riding by non-members on the services created by the group. ${ }^{48}$ The response of any such group is to limit the rights of membership and restrict how participants, deal with third parties. ${ }^{49}$ Among the common strategies that these groups used to ensure both loyalty to the group and reduced incentives to engage in opportunistic behavior was setting rates for commissions. ${ }^{50}$ In modern terms, such price fixing may seem questionable, but it was then the received wisdom of every private commodity and stock exchange that

43. Id. at 40 .

44. Anderson v. United States, 171 U.S. 604, 612-13 (1898); Hopkins v. United States, 171 U.S. $578,587-88(1898)$.

45. Hopkins, 171 U.S. at $579-580,587$.

46. Anderson, 171 U.S. at 613.

47. For a discussion of this aspect of joint ventures in commodity and securities trading markets, see generally, Carstensen, supra note 8.

48. See generally Carstensen, supra note 8 .

49. Id.; see also Anderson v. United States, 171 U.S. 604, 611 (1898) (regulating livestock traders); Hopkins v. United States, 171 U.S. 578, 581-82 (1898) (same); Bd. Of Trade v. United States, 246 U.S. 231, 239-41 (1918) (regulating grain traders).

50. See, e.g., Anderson, 171 U.S. at 611; Hopkins, 171 U.S. at 581. 
such limits were an essential component of such a venture..$^{51}$

In each instance, the group of traders needed a set understanding about how they would transact, including various ways to insure the reliability of their trades. In retrospect, there are legitimate questions concerning the need for, as well as the scope of, the restraints adopted. Indeed, this seems to have been the Government's position rather than a claim that the joint enterprises were in themselves illegal. ${ }^{52}$ The important distinction was that there was a legitimate underlying venture which itself was at risk from various kinds of strategic conduct and so plausibly would need to impose some membership rules on its participants. ${ }^{53}$ Without asserting in any way that the specific restraints imposed in the Anderson and Hopkins cases were necessary to the ventures, it is nevertheless evident that any exchange must have some membership rules if it is to survive as an enterprise.

Justice Peckham, the author of all of these decisions was a "strict constructionist" in his approach to section 1 . The statute expressly stated that "[e]very contract, combination in the form of trust or otherwise, or conspiracy, in restraint of trade . . is declared to be illegal." 54 The challenge for Justice Peckham was to give meaning to that formulation. Moreover, he confronted in both Trans-Missouri and Joint-Traffic the argument that many lawful partnerships and other comparable transactions involved agreements to restrict the competitive freedom of one or more parties. ${ }^{55}$ Such agreements are essential to a workable market in corporate assets and to the implementation of various kinds of collective enterprises and business transactions.

Justice Peckham's solution was to separate what he called "direct" restraints from those that were indirect, or "collateral," and therefore not within the scope of the statutory language. ${ }^{56}$ His explanation for this differentiation was that Congress intended to condemn all "restraints" of trade, but that it could not have meant to condemn every agreement that had a restraint in it. 57 Thus, he implicitly gave a limited definition to the term. By defining statutory "restraints" in this way, Justice Peckham was able to preserve the absolute language of section 1 without imposing an irrational constraint on business.

In Trans-Missouri, Justice White dissented on behalf of himself and

51. It was only in the 1970 s that the Department of Justice undertook a campaign to eliminate commission fixing on exchanges. See generally William F. Baxter, NYSE Fixed Commission Rates: A Private Cartel Goes Public, 22 Stan. L. Rev. 675 (1970).

52. Hopkins, 571 U.S. at 584-86. The relief nominally sought was an injunction against the entire organization, but the focus of concern was on certain restraints placed on members by the charter of the organization. Id.

53. A modern point of comparison is Northwest Wholesale Stationers, Inc. v. Pacific Stationary \& Printing Co., 472 U.S. 284 (1985).

54. 15 U.S.C. $\$ 1$ (2000) (emphasis added).

55. See United States v. Joint-Traffic Ass'n., 171 U.S. 505, 567-68 (1898); United States v. Trans-Missouri Freight Ass'n, 166 U.S. 290, 329 (1897).

56. Joint-Traffic, 171 U.S. at 565,568 . The opinion uses the term "direct" and calls other restraints "collateral" rather than indirect. See id. at 568.

57. Id. 
three other justices. ${ }^{58}$ The dissent has particular salience in the traditional doctrinal story because Justice White went on to be the Chief Justice and wrote the majority opinions in Standard Oil and American Tobacco, which proclaimed, but never defined, the rule of reason. ${ }^{59}$ Hence, the Trans-Missouri dissent is regarded as reflecting Justice White's, and therefore the Court's, understanding of the rule of reason. ${ }^{60}$

White's dissent is the classic consequentialist rejection of a per se rule for naked price fixing or market allocation. He contended that courts are capable of determining the correctness of prices (or any other restraint) created by cartels, and so no restraint should be unlawful unless it is substantively unreasonable. ${ }^{61}$ This position, in all fairness, is consistent with a great deal of contemporary state law analysis on restraint of trade as a contract issue. ${ }^{62}$ It was this body of state case law that Judge Taft, in Addyston Pipe, condemned as courts setting "sail on a sea of doubt."63 Indeed, the Restatement (Second) of Contracts reached the same conclusion that Judge Taft did: naked restraints of competition are invalid contract terms. ${ }^{64}$

Thus, the Trans-Missouri opinions presented two options for interpreting an antitrust law. One option would focus on the function of the restraint while the other would use an open-ended, unstructured weighing of the merits and demerits of the particular restraint.

The downside of Justice Peckham's binary approach to section 1 is evident in the Hopkins and Anderson decisions because Justice Peckham left the courts no room to review the merits of restraints that were ancillary to a lawful joint enterprise. ${ }^{65}$ For this reason, Judge Taft's proposed reading of section 1, although dicta in the context of the facts of Addyston Pipe, would have been preferable even though it departed substantially more from the language of the statute. Judge Taft would retain the per se condemnation of cartels and other naked restraints, but employ a "rule of reason" to review the merits of restraints that were in fact ancillary to joint ventures and transactions. ${ }^{66}$ Judge Taft's test was to ask if the re-

58. Trans-Missouri, 166 U.S. at 343. Justice White, joined by two other justices, dissented without opinion in Joint-Traffic, 171 U.S. at 578.

59. See United States v. Am. Tobacco Co., 221 U.S. 106, 179-80 (1911); Standard Oil Co. v. United States, 221 U.S. 1, 62 (1911).

60. See, e.g., Roger D. Blair \& David L. Kaserman, Antitrust Economics, 58 (2d ed. 2009); Lawrence A. Sullivan \& Warren Grimes, The Law of Antitrust: An INTEGRATED HANDBOOK 192 (2000) ("White's majority opinion . . . because it also made reasonableness 'the fulcrum, is sometimes said to have retreated from holdings in TransMissouri and Joint-Traffic'. . . [because of] Justice White's use of language borrowed from his dissent in the earlier case[s]. ...").

61. Trans-Missouri, 166 U.S. at 372-73.

62. See generally James May, Antitrust in the Formative Era: Political and Economic Theory in Constitutional and Antitrust Analysis, 1880-1918, 50 Oно Sт. L.J. 257 (1989).

63. United States v. Addyston Pipe \& Steel Co., 85 F. 271, 283-84 (6th Cir. 1898) aff d as modified, 175 U.S. 211 (1899).

64. Restatement (SeCOND) of Contracts $\$ 187$ (1981).

65. See Anderson v. United States, 171 U.S. 604, 615-20 (1898); Hopkins v. United States, 171 U.S. 578, 597-604 (1898).

66. Addyston Pipe, 85 F. at 282-83. 
straint was "reasonably necessary" to the transaction and no more anticompetitive than needed to achieve its primary goal in relation to that transaction. ${ }^{67}$ Unfortunately, in affirming Judge Taft's decision, the Supreme Court opinion, written by Justice Peckham, did not respond directly to his suggestion. ${ }^{68}$

Several sources of confusion arose in these early cases. As discussed previously, the absolutist terms that Justice Peckham used allowed opponents of antitrust law to paint it as anti-business. ${ }^{69}$ Secondly, some arguably populistic language in Trans-Missouri furthered the impression that the Court was hostile to all large enterprises. Finally, the then prevailing conception of interstate commerce and the dichotomous allocation of jurisdiction associated with that definition, limited the scope of federal jurisdiction. This narrow conception of interstate commerce is a confounding feature of the Hopkins and Anderson opinions.

With respect to the populist take on the early decision, opponents of antitrust law could combine the declaration that all "direct" restraints are unlawful with a passage of the Trans-Missouri opinion, in which Justice Peckham wrote:

It is wholly different, however, when such changes are effected by combinations of capital whose purpose in combining is to control the production or manufacture of any particular article in the market, and by such control dictate the price at which the article shall be sold; the effect being to drive out of business all the small dealers in the commodity, and to render the public subject to the decision of the combination as to what price shall be paid for the article. ... [T] he result in any event is unfortunate for the country, by depriving it of the services of a large number of small but independent dealers, who were familiar with the business, and who had spent their lives in it, and who supported themselves and their families from the small profits realized therein. ... [I]t is not for the real prosperity of any country that such changes should occur which result in transferring an independent business man, the head of his establishment, small though it might be, into a mere servant or agent of a corporation for selling the commodities which he once manufactured or dealt in; having no voice in shaping the business policy of the company, and bound to obey orders issued by others. Nor is it for the substantial interests of the country that any one commodity should be within the sole power and subject to the sole will of one powerful combination of capital. ${ }^{70}$

67. Id. at 281-82.

68. The opinion does quote from and speak positively of Judge Taft's opinion. See Addyston Pipe, 175 U.S. at 226 ("[T]he opinion of Circuit Judge Taft, delivered in this case in the circuit court of appeals, comprises, as we think, all that is essential to the discussion of the questions arising in this case. ....); see also id. at 235-38 (quoting at length from Judge Taft's opinion).

69. See supra text accompanying notes 54-57; see also Trans-Missouri, 166 U.S. at 372 73 (White, J., dissenting).

70. Trans-Missouri, 166 U.S. at 323-24 (emphasis added). 
The context of that statement is important. First, it was written as part of the explanation as to why the Court held that railroads were not exempt from antitrust law. Second, and more significantly, Justice Peckham, whose sympathy to social Darwinism is evident, declared immediately prior to the statement quoted above that:

[B]y reducing the expense inseparable from the running of many different companies for the same purpose[,] [t]rade or commerce under those circumstances may nevertheless be badly and unfortunately restrained by driving out of business the small dealers and worthy men whose lives have been spent therein, and who might be unable to readjust themselves to their altered surroundings. Mere reduction in the price of the commodity dealt in might be dearly paid for by the ruin of such a class and the absorption of control over one commodity by an all-powerful combination of capital. In any great and extended change in the manner or method of doing business it seems to be an inevitable necessity that distress, and, perhaps, ruin, shall be its accompaniment, in regard to some of those who were engaged in the old methods. A change from stagecoaches and canal boats to railroads threw at once a large number of men out of employment. Changes from hand labor to that of machinery, and from operating machinery by hand to the application of steam for such purpose, leave behind them, for the time, a number of men who must seek other avenues of livelihood. These are misfortunes which seem to be the necessary accompaniment of all great industrial changes. It takes time to effect a readjustment of industrial life so that those who are thrown out of their old employment by reason of such changes as we have spoken of may find opportunities for labor in other departments than those to which they have been accustomed. It is a misfortune, but yet in such cases it seems to be the inevitable accompaniment of change and improvement. ${ }^{71}$

What he contends is the harm that results from cartels and other naked restraints is that they eliminate competitors not through greater efficiency or innovation, but instead by their power to exclude others from the market. Thus read, the statement is anything but a call for small business protectionism. Instead, it is an emphatic affirmation that the function of the restraint in context is what is essential to its status under antitrust law.

The final confusing factor in these old cases is the limited scope of interstate commerce and its role in Anderson and Hopkins. Some read the decisions as having excluded liability only because the activities involved were in intra-state commerce. ${ }^{72}$ This is hard to square with the fact that the stockyard itself physically straddled the border between Kansas and Missouri so that some transactions were literally interstate. ${ }^{73}$ More importantly, the discussion, while less than transparent in the opinion, appears to argue that the venture did not affect interstate commerce in

71. Id. at 323 (emphasis added).

72. See, e.g., ABA Antitrust Section, Monograph No. 23, The Rule of Reason 40 (1999).

73. Hopkins v. United States, 171 U.S. 578, 579 (1898). 
order to explain that the real issue was the internal organization of the venture, which made it thus-like E. C. Knight ${ }^{74}$-outside the scope of interstate commerce concern. ${ }^{75}$ However, the underlying basis for that conclusion was the nature of the relationship of the restraints to the venture which, in turn, made their impact on commerce only indirect. Justice Peckham's narrow view of the scope of section 1 is most evident in the Northern Securities case, where he joined the dissenters. ${ }^{76}$

The Northern Securities decision highlights two issues. First, the meaning of the concept of a "restraint of trade," and second, the scope of federal jurisdiction over the conduct of corporations, including the creation of corporations and their ownership of stock in other enterprises. All four opinions in the case concurred that the Northern Securities holding company was anticompetitive in the sense that it would eliminate competition in rail service across the Northern tier of states from Wisconsin to the Pacific coast. ${ }^{77}$ Indeed, the stockholders' express reason for pooling the railroad interests was to eliminate competition between the two major lines. ${ }^{78}$ But did a holding company that acquired the stock in two competing railroads constitute a restraint of trade in or affecting interstate commerce as that legal concept was then understood?

The defendants argued that the corporate laws of New Jersey expressly authorized a corporation to purchase the stock of other corporations. ${ }^{79}$ Relying on contemporary corporate law decisions, the defendants claimed that New Jersey corporate law alone determined the rights of Northern Securities to acquire stock interests in other railroads. The plurality and the concurrence both rejected this contention. ${ }^{80}$ Railroads were themselves instruments of interstate commerce and, as such, transactions involving the ownership and control of such instruments could not be immunized from federal law by reference to a state statute. ${ }^{81}$ This was especially true when the authorizing state had no direct connection to the territory in which the railroads involved competed. Moreover, the transfer of control over the railroads was an act that directly affected interstate commerce. Thus, the plurality and the concurrence found no obstacle inhibiting them from applying antitrust law to the combination. ${ }^{82}$ From a contemporary perspective, it is striking how much effort the plurality expended in explaining a proposition that today seems obvious.

74. United States v. E.C. Knight Co., 156 U.S. 1 (1895).

75. See, e.g., id. at 586-90.

76. N. Sec. Co. v. United States, 193 U.S. 197, 364 (1904) (Holmes, J., dissenting); id. at 411 (White, J., dissenting).

77. Id. at 326-28 (plurality opinion); id. at 362 (Brewer, J., concurring); id. at 409 (Holmes, J., dissenting); id. at 396 (White, J., dissenting).

78. See United States v. N. Sec. Co., 120 F. 721, 723-24 (8th Cir. 1903).

79. Id. at $332-34$

80. Id. at 349-351, 363-364.

81. Id. at 353 (plurality opinion) (citing United States v. Trans-Missouri Freight Ass'n, 166 U.S. 290, 332 (1897)).

82. Id. at 353 (plurality opinion); id. at 363 (Brewer, J., concurring). 
Justice White dissented, joined by the Chief Justice, Justice Peckham, and Justice Holmes, in an opinion that rejected what he characterized as an expansion of federal power and diminution of state authority over corporations. ${ }^{83}$ His central arguments included the assertion that an individual could have bought controlling interests in the three railroads involved without violating antitrust law. ${ }^{84}$ Viewed in light of the Court's modifications of its interstate commerce notions over the next few years, this argument is strikingly backward looking. Moreover, it highlights a legal formalism about interstate commerce and the ownership of various kinds of productive assets that is difficult to appreciate today.

The railroads' second point of emphasis was that the combination of control over the railroads was not itself a "restraint" in the sense that there was no overt agreement to restrict the freedom of action of any line. ${ }^{85}$ This argument builds on prior decisions of the Court such as Trans-Missouri and Joint Traffic, finding violations of the Sherman Act because the agreement contained direct limits on the parties' competition. ${ }^{86}$ A component of this argument, but not one that was emphasized, was that a holding company was a means to consolidate control over assets and, in doing so, create a more efficient and viable competitor ${ }^{87}$ Any illegal elimination of competition among actual competitors as a result of combination would arguably raise serious concerns about the scope of antitrust law.

The plurality's response was not very satisfactory on this point. It essentially reiterated that the specific holding company was a "direct restraint" on competition. ${ }^{88}$ This point is strongly reinforced by the concurrence, which specifically declared that only those combinations among competitors that resulted in direct restraints on competition were illegal under the act. ${ }^{89}$ It is fairly easy to parse this declaration and to read it back into the plurality decision. These five Justices saw the Northern Securities holding company as an alternative form of a cartel consolidating control over competition in the Northern tier of states. As such, it was nothing but a naked restraint. In support of this conclusion, it is relevant that Northern Securities did not integrate the operation of the three railroads. ${ }^{90}$ It acted only to control rates and pool profits, which were then distributed pro-rata among the owners of its stock. ${ }^{91}$ Further, the holding company did not own one-hundred percent of the railroads. In fact, it primarily consolidated the interests of Morgan, Hill and Harriman,

83. Id. at 369-70, 393-98 (White, J., dissenting).

84. Id. at 409.

85. Id. at 354 (plurality opinion).

86. See N. Sec. Co. v. United States, 24 S. Ct. 436, 436 (1904) (stating appellant's arguments).

87. United States v. Joint-Traffic Ass'n, 171 U.S. 505, 559-60 (1898); United States v. Trans-Missouri Freight Ass'n, 166 U.S. 290, 312 (1897).

88. Id. at 354.

89. Id. at 361-64 (Brewer, J., concurring).

90. United States v. N. Sec. Co., 120 F. 721,724 (8th Cir. 1903).

91. Id. 
the three dominant investors in the competing railroads, although other shareholders were invited to exchange their stock in either line for Northern Securities shares. ${ }^{92}$ By the time the case got to court, Northern Securities held ninety-six percent of the Northern Pacific, but only seventysix percent of Great Northern. ${ }^{93}$ The weakness in the plurality opinion is that it does not acknowledge either the fact that some horizontal combinations would only create "indirect" restraints or the fact that only those combinations creating significant market power were of the sort that fit the prohibition of section 1 . The concurring opinion, at best, only partially overcomes this deficiency.

Justice Holmes, who had no use for the Sherman Act in any event, argued in his dissent for an extremely narrow definition of "restraint"one that would effectively immunize all mergers and holding companies from antitrust law. ${ }^{94}$ To do this, he adopted the narrow definition of the restraint concept advanced by the defendants and argued that there was a clear contrast between a holding company and the cartels condemned in Trans Missouri, Joint Traffic, Addyston Pipe, and Montegue. ${ }^{95}$ For Justice Holmes-who was joined by the Chief Justice, Justice White, and Justice Peckham, Northern Securities was a form of corporate organization like the combination of sugar refiners in E.C. Knight. ${ }^{96}$ Moreover, Holmes read the Knight decision to treat any acquisition of stock or assets as outside the scope of restraint of trade. ${ }^{97}$ Because he conceded that the merger raised serious risks of anticompetitive effects, he emphasized that control over such combinations was a function of state corporate law and not federal antitrust law. ${ }^{98}$

Thus, the central disputes between the majority and the dissenters focused on the scope of jurisdiction of federal courts to review corporate acquisitions of stock and the legal standard for evaluating the merits of any such transaction. On both counts, the dissenters propounded backward looking analyses that would have gutted antitrust law. The majority had the more realistic appraisal of the necessary scope of national oversight over corporate combinations. Indeed, even the plurality and the concurrence took what today might well seem an unduly narrow view of what made the holding company illegal. Those opinions imply that a holding company was illegal only if it imposed a direct restraint on competition so that it was functionally similar to the cartels condemned in earlier restraint of trade cases. This, in turn, would suggest that a full fledged merger or other consolidation among competitors would not violate section 1 , despite its express condemnation of "every contract ... in

92. Id.

93. Id.

94. N. Sec. Co., 193 U.S. at 403-11 (Holmes, J., dissenting).

95. Id. at $405-06$.

96. Id. at $402-10$.

97. Id. at 410 .

98. Id. at $408-09$. 
the form of trust or otherwise, . . . in restraint of trade."99 Indeed, the opinions may have meant that the Peckham dichotomy still governed antitrust law. However, it is equally plausible that the majority felt that they did not need to go beyond the criteria created in Trans-Missouri and Joint-Traffic to condemn this specific agreement.

Despite the potential for a very limited interpretation of the decision, the legal academy joined Justice Holmes in creating a hysterical response, claiming that the majority would condemn every merger among competitors. ${ }^{100}$ This is a classic illustration of how the meaning of a decision can be lost in doctrinal translation done for strategic purposes. Hence, there was a continuing assertion in academic and business commentary that the law as interpreted in Northern Securities had somehow outlawed all consolidations among competing businesses. ${ }^{101}$

The period from 1904 to 1911 continues the pattern of the prior cases. The Court consistently condemned naked restraints of competition ${ }^{102}$ and began to feel its way toward the use of the Taft framework for examining "indirect" or ancillary restraints. This is clearest in a case from Oklahoma involving the use of covenants not to compete in connection with the purchase of cotton gins. ${ }^{103}$ Such agreements were, and still are, common features of the sales of businesses. But these agreements were of very long duration and covered vast territories-well beyond the time and place reasonably necessary to protect any legitimate interest of the buyer in capturing the goodwill associated with some specific enterprise. ${ }^{104}$ Despite the "indirect" nature of the restraints, the Court upheld their condemnation as a matter of contract law. ${ }^{105}$

In sum, the early history of antitrust decisions is more internally consistent and focused on the business function of the restraint. When it was naked, it was condemned. When it was associated with a legitimate joint enterprise or transaction, the Court gradually moved from categoric lawfulness to a more nuanced review of the justification for the restraint in terms of the legitimate needs of the venture.

99. 15 U.S.C. $\$ 1$ (2006) (emphasis added).

100. Articles asserting that the Northern Securities case would destroy modern industry include Christopher C. Langdell, The Northern Securities Case and the Sherman Anti-Trust Act, 16 Harv. L. Rev. 539, 542-49 (1903); Christopher C. Langdell, The Northern Securities Case Under a New Aspect, 17 HARv. L. REv. 41, 41 (1904), and F.C.G., The Merger Case, 17 HaRv. L. Rev. 474, 476-78 (1904). This stream of "scholarship" came to an end after Sir Frederick Pollack, an English legal scholar and friend of Holmes, wrote a short article pointing out that the decision rested on essential fact findings that showed this particular holding company to have an anticompetitive function. Frederick Pollack, The Merger Case and Restraint of Trade, 17 HaRv. L. Rev. 151, 154 (1904); see also Herbert Pope, The Legal Aspect of Monopoly, 20 Harv. L. Rev. 167, 182-84 (1907). Despite the quelling of the worst of the scholarly indignation, the literature did not produce a major restatement of antitrust law based on the functional analysis.

101. Langdell, The Northern Securities Case Under a New Aspect, supra note 100, at 43 44; F.C.G., supra note 100 , at $478-79$.

102. See, e.g., Swift \& Co. v. Untied States, 196 U.S. 375 (1905).

103. Shawnee Compress Co. v. Anderson, 209 U.S. 423, $433-34$ (1908).

104. Id. at 435 .

105. Id. 


\section{THE STANDARD OIL RULE OF REASON AND ITS RELATION TO THE EARLY YEARS}

It is frequently contended that when Chief Justice White wrote the Supreme Court decisions deciding Standard Oil ${ }^{106}$ and American Tobacco,${ }^{107}$ he was writing the rule of reason he had advocated in TransMissouri ${ }^{108}$ into the Sherman Act. ${ }^{109}$ To be sure, neither opinion provides a clear and lucid statement of the rule and its application. Indeed, there are those who would suggest that the Chief Justice meant only to say that courts should be ruled by reason in the interpretation of a statute-hence there is a rule of reason. ${ }^{110}$ More likely, he recognized, as has everyone thereafter, that mere possession of a monopoly can not be in and of itself illegal. Hence some criteria must exist to determine when the possessor of a monopoly has acted unlawfully. Moreover, those criteria should be "reasonable." The question of what makes a monopoly illegal as well as how to remedy an illegal monopoly are recurring questions for antitrust lawyers, scholars, and judges. Ultimately, the two decisions can not provide very helpful responses to either question, but in context they are suggestive of the alternative approaches that might frame decisions on the merits as well as addressing the remedy question in a way that is interestingly responsive to concerns about conduct-oriented decrees that might create "false positives."111 This part will only address the question of what Justice White might have meant by a "rule of reason" in relation to contracts in restraint of trade (both Standard Oil and American Tobacco were challenged as violations of both section 1 and section 2).

To appreciate the probable meaning of the rule of reason to the Court as a whole, it is important to recognize that Dr. Miles ${ }^{112}$ was argued and decided at the same time as Standard Oil and American Tobacco. ${ }^{113}$ Hence, it is unimaginable that Charles Evan Hughes, the author of $D r$. Miles and a member of the majority in both the monopoly cases, was

106. Standard Oil Co. v. United States, 221 U.S. 1 (1911).

107. United States v. Am. Tobacco Co., 221 U.S. 106 (1911).

108. United States v. Trans-Missouri Freight Ass'n, 166 U.S. 290 (1897).

109. Martin I. Sklar, The Corporate Reconstruction of American Capitalism, 1890-1916: The Market, the LaW, and Politics 146-48 (1988).

110. William Letwin, Law and Economic Policy in America: The Evolution of the Sherman Antitrust Act 261-62 (1965) (citing Standard Oil Co. v. United States, 221 U.S. 1, 64 (1911)).

111. For an expansion of this point, see generally Peter C. Carstensen, False Positives in Indentifying Liability for Exclusionary Conduct: Conceptual Error, Business Reality, and Aspen, 2008 WIS. L. REv. 295.

112. Dr. Miles Med. Co. v. John D. Park \& Sons Co., 220 U.S. 373, 373 (1911).

113. Id. at 374. Although the Dr. Miles opinion is in the volume prior to the Standard Oil and American Tobacco decisions, the three cases were argued in sequence and the opinions were being drafted at the same time. The arguments were on January 4 and 5 , 1911 in Dr. Miles, 220 U.S. at 373. United States v. American Tobacco Co., 221 U.S. 106 (1911), was reargued on January 6 and January 9-12, 1911. Standard Oil Co. of New Jersey v. United States, 221 U.S. 1 (1911), was reargued January 12, 13, 16 and 17, 1911. Both Standard Oil and American Tobacco had been first argued to the Court in 1910 but not in sequence. See Standard Oil, 221 U.S. at 1; Am. Tobacco, 221 U.S. at 108. 
either unaware of or intended to deviate from the rule of reason being crafted in those cases. Similarly, Chief Justice White, the author of the monopoly opinions, voted for the $D r$. Miles decision rather than joining Justice Holmes's dissent. ${ }^{114}$

Dr. Miles Medical Company (Dr. Miles), employed resale price maintenance and required its wholesalers and retailers to sell its products at set prices. ${ }^{115}$ It sued John D. Park \& Sons (Park), a drug wholesaler that had obtained Dr. Miles's products from both retailers and wholesalers and then resold them to discounters. Technically, Dr. Miles's claim was that Park had interfered with Dr. Miles's contracts with its official distributors and retailers. ${ }^{116}$ As an affirmative defense, Park contended that Dr. Miles's resale price maintenance was unlawful. ${ }^{117}$ The court of appeals upheld the trail court's dismissal of Dr. Miles's complaint, concluding that the contracts were invalid on their face. ${ }^{118}$ The decision below expressly applied Judge Taft's ancillary restraint analysis and found that Dr. Miles had not in fact offered any legitimate business justification for restraining resale prices. ${ }^{119}$

Justice Hughes's analysis in the Dr. Miles opinion is functional once again. He rejects any claim of inherent entitlement (based on either trade secrets or production of a differentiated, trade-marked good) to impose restrictions on the resale of the products. ${ }^{120}$ But he acknowledges that such restraints can be lawful as a matter of contract law. ${ }^{121}$ Thus, the decision does not in fact declare all resale price maintenance per se illegal. Rather, the Court affirmed the lower court's finding that the facts set forth by the plaintiff, Dr. Miles, did not justify the imposition of a restraint. ${ }^{122}$ Basically, Dr. Miles only asserted that it wanted to protect its distributors from price competition and preserve their margins. ${ }^{123}$ Thus, it set itself up as a cartel manager probably at the insistence of the drug stores and the National Association of Retail Pharmacists. ${ }^{124}$ It is possible that additional facts might exist that could have provided a stronger

114. Dr. Miles, 220 U.S. at 409.

115. Id. at 395 .

116. Id. at 395-96.

117. Id. at $399-400$.

118. Dr. Miles Med. Co. v. John D. Park \& Son Co., 164 F. 803, 805-07 (6th Cir. 1908).

119. See id. at 805-06. Dr. Miles largely argued a property right claim to control resale based on the trade secrets involved in the manufacture of its "patent" medicines. Id.; see also May, supra note 62, at 389-91.

120. Dr. Miles, 220 U.S. at 404-05. This passage, which relies on the ancient rule against restraints on alienation for chattels, is often misread as a declaration that no contract imposing restraints can accompany the sale of goods. A more careful reading of the text would have avoided this error.

121. Id. at 406.

122. Id. at 408 .

123. Id.

124. See Joseph Cornwall Palamountain, Jr., The Politics of Distribution 94 (1955); cf. Ward S. Bowman, Jr., The Prerequisites and Effects of Resale Price Maintenance, 16 U. CHI. L. Rev. 825 (1955); Lester G. Telser, Why Should Manufacturers Want Fair Trade?, 3 J.L. \& ECON. 86, 99-104 (1960) (explaining the belief that retailers pressure manufacturers into implementing resale price maintenance). 
justification for some form of resale price controls. ${ }^{125}$ However, the pleadings in the case, the basis for decision, were bereft of any assertion of free-riding or other functionally legitimate justification for the restraint. Indeed, Justice Hughes makes the point explicitly in his opinion:

The bill asserts [only] the importance of a standard retail price, and alleges generally that confusion and damage have resulted from sales at less than the prices fixed. . . . It is through the inability of the favored dealers to realize these profits, on account of ... competition, that the complainant works out its alleged injury. . . . [T]he complainant can fare no better with its plan ... than could the dealers themselves if they formed a combination and endeavored to establish the same restrictions. . . But agreements or combinations between dealers, having for their sole purpose the destruction of competition and the fixing of prices, are injurious to the public interest and void. ... The complainant's plan falls within the principle which condemns contracts of this class. It, in effect, creates a combination for the prohibited purposes. ${ }^{126}$

Since Chief Justice White joined the Dr. Miles opinion, it follows that the rule of reason he embraced in Standard Oil and American Tobacco is not the same test of reasonableness that he proposed more than a decade earlier in Trans-Missouri. Indeed, in both Standard Oil and American Tobacco, he explicitly stated that the standard of reasonableness being adopted was consistent with the outcome of all the earlier cases, including Trans-Missouri. ${ }^{127}$ No clearer evidence could exist that Justice White had changed his position on the rule of reason.

The implication of reading $\mathrm{Dr}$. Miles in conjunction with Standard Oil and American Tobacco is that the Court had adopted and retained the Peckham-Taft distinction between naked and ancillary restraints. Moreover, in light of the fact that both Standard Oil and American Tobacco involved holding companies that had acquired the stock of competing firms to achieve their respective monopolies, the implication of these decisions is that Justice White no longer adhered to the narrow definition of restraint of trade advanced by Justice Holmes in Northern Securities and had abandoned as well his own position that corporate consolidations were not within the scope of federal jurisdiction. Thus, the case law through the formative years is much more consistent with a functional

125. See Rudolph J.R. Peritz, "Nervine" and Knavery: The Life and Times of Dr. Miles Medical Company, in ANTITRust Stories 73-80 (Dan Crane \& Eleanor Fox eds., 2007).

126. Dr. Miles, 220 U.S. at 407-08 (emphasis added). Among the cases cited in this passage was Judge Taft's opinion in United States v. Addyston Pipe \& Steel Co., 85 F. 271 (6th Cir. 1898), further confirming that the Court was rejecting Dr. Miles's claim of a right to impose resale price maintenance by contract because Dr. Miles had failed to allege a legitimate justification for such a restraint.

127. Standard Oil Co. v. United States, 221 U.S. 1, 66-69 (1911); United States v. Am. Tobacco Co., 221 U.S. 106, 179 (1911). These passages expressly embraced the "direct-indirect" language used by Justice Peckham and cited his examples thus confirming that the "naked-ancillary" distinction was indeed the central functional issue. 
approach once cases are read in the context of the specific arguments made and the doctrinal analyses actually proffered by the Court.

\section{THE MISREADING OF DR. MILES}

As discussed earlier, the $\mathrm{Dr}$. Miles decision in reality held only that the specific contractual restraints at issue were on their face unreasonable because they lacked a legitimate business justification. ${ }^{128}$ Dr. Miles had alleged only that its customers were unhappy when they faced price competition and that the resale price maintenance was to protect them from such competition. ${ }^{129}$ The decision as a whole reviews and rejects the primary defense that Dr. Miles offered, which was that it had an inherent right to restrict the distribution of its products. ${ }^{130}$ It is in the context of that discussion that the Court made reference to the ancient rule against restraints on alienation of personal property. ${ }^{131}$ Indeed, that ancient rule still makes a great deal of sense as the base point for public policy. If there is reason to restrict the use or resale of such property, it can and should be accomplished by contract. This is what the Dr. Miles decision strongly emphasized. ${ }^{132}$ Moreover, this same insight underlies the recent patent law decision in $L C$ Electronics v. Quanta, where the Supreme Court rejected an effort by the Federal Circuit to create a patent law doctrine that would allow patent owners to impose restraints on remote parties as an inherent right of the patent. ${ }^{133}$ The Court also emphasized, consistent with the Dr. Miles analysis, that a patent holder could enter into lawful contracts in connection with the sale of its patented good. ${ }^{134}$

One of the most interesting coalitions in support of resale price maintenance is that of Robert Bork and Louis Brandeis. Following Dr. Miles, Justice Brandeis was a vigorous advocate for statutory action to reverse that decision. ${ }^{135}$ His rationale was that small businesses could not compete effectively with larger, more efficient enterprises. ${ }^{136}$ Hence, to protect his favored class he wanted to allow resale price maintenance (RPM). ${ }^{137}$ Business historian Thomas McCraw has chronicled this history in substantial detail. His conclusion is that Justice Brandeis was, in reality, the proponent and protector of the petit bourgeois and not truly the "people's lawyer" of popular imagination. ${ }^{138}$ Justice Brandeis suc-

128. See supra text accompanying notes 114-26.

129. Dr. Miles, 220 U.S. at 374-75.

130. See id. at 406.

131. Id. at 404-05.

132. Id. at 405 ("Whatever right the manufacturer may have to control beyond his own sales must depend not upon an inherent power incident to production and original ownership, but upon agreement.").

133. Quanta Computer, Inc. v. LG Elecs., Inc., 128 S. Ct. 2109, 2118-19 (2008).

134. Id. at 2122 n.7.

135. Thomas K. McCraw, Prophets of Regulation 94-142 (1984).

136. Id. at $102-08$.

137. Id. at 103 .

138. Id. at 141; see also Thomas K. McCraw, Rethinking the Trust Question, in RegulAtion in Perspective: Historical Essays 45 (Thomas K. McCraw ed., 1981) (reporting 
ceeded in his campaign in the 1930s, which resulted in the Miller-Tydings Act, later strengthened by the McQuire Act, which allowed states to authorize RPM and enforce it against non-conforming sellers. ${ }^{139}$ These statutes were repealed in 1976 when Congress concluded that allowing such price fixing did not serve the public interest in competitive markets. ${ }^{140}$

Bork in his work makes Justice Brandeis and his pro-small business view of antitrust the great force of evil that distorted and misled courts for decades. ${ }^{141}$ Yet Bork strongly defends RPM as necessary for producers to protect their retailers from unfair competition. ${ }^{142}$ In Bork's version, however, the manufacturer imposes prices (or other restraints) that are reasonably necessary to protect some legitimate interest of the producer in the distribution process. ${ }^{143}$ Bork ignores the fact that this defense for RPM is entirely consistent with the decision in Dr. Miles and that the defendants in RPM cases in fact did not advance such justifications. ${ }^{144}$

Thus, Bork and Justice Brandeis have diametrically opposed theories for why RPM would exist. Moreover, Bork logically would reject Justice Brandeis's theory because it justifies a naked restraint of competition and so would result in higher consumer prices without any consumer gain. Justice Brandeis would not reject Bork's claim but would, presumably, say that efficiency gained from improved distribution is only one of the justifications for RPM.

Doctrinally, the Dr. Miles inquiry into the merits of the justification for the price restraint was lost over time as courts and commentators came to see the decision as a "per se" condemnation of RPM."145 The doctrinal history after $D r$. Miles reflects a continued effort by defendants to deny either that there was a sale or that there was an agreement to fix resale prices. ${ }^{146}$ In essence then, the defendants in these cases failed to set forth

that Brandeis was a participant in the administration of a cartel in the shoe industry in the $1890 \mathrm{~s})$.

139. The McGuire Act, Pub. L. No. 542, 66 Stat. 631, 632 (1952) (repealed 1975).

140. Consumer Goods Pricing Act of 1975, Pub. L. No. 04-145, § 2, 89 Stat. 801 (1975); see also S. Rep. No. 94-466, at 1 (1975).

141. Robert H. Bork, The Antitrust Paradox: A Policy at War with Itself 41-47 (1978).

142. Id. at $288-91$.

143. Id.

144. The possible exception is United States v Univis Lens Co., 316 U.S. 241, 249 (1942), where arguably the defendant made such an argument. However, the facts of the case as reported show that there was in fact no risk of free-riding. Indeed, the Supreme Court has clearly indicated in the Quanta decision that Univis Lens is still good law. Quanta Computer, Inc. v. LG Elecs., Inc., 128 S. Ct. 2109, 2115-20 (2008).

145. See, e.g., BORK, supra note 141, at 281 ("Vertical price fixing . . . has been illegal per se ... since the Dr. Miles case ....").

146. See, e.g.,United States v. Parke, Davis \& Co., 362 U.S. 29 (1960); United States v. General Elec. Co., 272 U.S. 476, 479 (1926); United States v. Colgate \& Co., 250 U.S. 300, 305 (1919). 
any legitimate justification for their restraints. ${ }^{147}$ Hence, the explanation for resale price maintenance in these cases must lie in other gains to either the producer or the retailers. ${ }^{148}$

In Leegin, ${ }^{149}$ the Court might well be understood to have reinvented the Dr. Miles analysis except that it did not do what the Dr. Miles Court had done in asking whether the purported justifications for the restraint were legitimate. Here, the loss of a good understanding of what the $D r$. Miles Court actually said and how it analyzed the allegations in the complaint may well be a significant factor in the Leegin Court's fuzzy analysis. Instead of expressly returning to the $\mathrm{Dr}$. Miles standard, the majority speculated at length about the potential for some legitimate justification for such restraints. ${ }^{150}$ This speculation occurred in the context of the sale of women's purses and related leather goods. ${ }^{151}$ Such products do not involve either very complex technology or sophisticated selling. Thus, the interesting question, never discussed, is what possible justification could exist for restricting the resale price of purses? Even if the Court was not willing to decide the merits of this particular manufacturer's justifications, it might have followed Dr. Miles and specified the kinds of justifications that would have been legitimate. Indeed, the most recent reports on the re-emergence of RPM offer justifications for imposing resale price restraints that are very questionable in terms of economic efficiency or any legitimate need of the parties. ${ }^{152}$ Indeed, they resonate very much with the claims of Dr. Miles, which the Court rejected because their "sole purpose" was to create a cartel for the benefit of the dealers. ${ }^{153}$ The goal of these restraints appears to have been raising consumer prices for the benefit of favored retailers and to the detriment of those retailers willing to offer lower prices. ${ }^{154}$ Thus, most, perhaps all, current RPM would fail the Dr. Miles reasonableness test. But that test has been lost in the doctrinal translation of that decision.

Vertical restraints may facilitate efficient distribution, or they may instead exploit consumers and exclude equally efficient competitors. Sometimes, they have both effects. If the Court were more attentive to

147. Steven P. Schneider, Comment, A Functional Rule-of-Reason Analysis for the Law of Resale Price Maintenance and Its Application to Spry-Rite v. Monsanto, 1984 WIS. L. REV. 1205, 1230-43 (surveying the products involved).

148. For plausible anticompetitive explanations for such restraints, see Peter C. Carstensen, The Competitive Dynamics of Distribution Restraints: The Efficiency Hypothesis Versus the Rent-Seeking, Strategic Alternatives, 69 ANTITRust L. J. 569 (2001) and Warren S. Grimes, Spiff, Polish, and Consumer Demand Quality: Vertical Price Restraints Revisited, 80 CAL. L. REV. 815, 820-23 (1992).

149. Leegin Creative Leather Prods., Inc. v. PSKS, Inc., 127 S. Ct. 2705 (2007).

150. Id. at $2713-20$.

151. Id. at 2710.

152. Joseph Pereira, Discounter, Monitors Face Battle on Minimum Pricing, Wall St. J., Dec. 4, 2008, at A1, available at http://online.wsj.com/article/SB122835660256478297. html.

153. Dr. Miles, 220 U.S. at 408.

154. See generally Carstensen, supra note 148 (presenting an analysis of various distribution restraints to show that they can serve anti-competitive purposes rather than enhancing efficient distribution). 
the underlying facts of Dr. Miles and the other resale price maintenance cases it has decided, it would have recognized that such price restraints have rarely, if ever, served the Borkian goal of efficiency, but have often facilitated exploitation and exclusion. Such a functional review of the history of the doctrine would have explained why it commanded respect and support from Supreme Court Justices over ninety years. Moreover, such a review ought to have counseled great caution against an open-ended, imprecise test for the reasonableness of such restraints. Unfortunately, the lessons of history were ignored.

\section{THE BASIS FOR UPHOLDING HORIZONTAL RESTRAINTS-THE PER SE-RULE OF REASON DISTINCTION}

The final doctrinal confusion also with a strong historical root, is the effort to explain when an agreement involving restraints on competition among competitors is lawful. On the one hand, the conventional doctrinal statement is that all horizontal restraints are illegal, but the history of Supreme Court decisions starting with Anderson ${ }^{155}$ and Hopkins ${ }^{156}$ in 1898 and running through Dagher ${ }^{157}$ in 2006 , show the absolute falsity of this simplistic statement. This discussion will not rehash the entire history of the doctrinal confusion about horizontal restraints. Instead, it will examine three of the foundation cases to show that they are internally consistent doctrinally. Moreover, a focus on the underlying factualfunctional analyses of these cases would have avoided a great deal of doctrinal confusion. The three cases are the Chicago Board of Trade, ${ }^{158} \mathrm{Ap}$ palachian Coals, ${ }^{159}$ and Socony. ${ }^{160}$

I have elsewhere written at length about the Chicago Board of Trade case. ${ }^{161}$ The central conclusion of that detailed review of the case record as well as the internal records of both the Government and the Board of Trade (the Board) is that the restraints on prices imposed on after hours buying (the "call rule") were in fact ancillary to the efficient operation of the Board. ${ }^{162}$ The Board was a joint venture among its members to create an efficient, partial integration of their activities as buyers and sellers of grain. ${ }^{163}$ The Board provided a forum for transactions, much as the Kansas City stockyards had in Anderson and Hopkins, and a variety of

155. Anderson v. United States, 171 U.S. 604 (1898).

156. Hopkins v. United States, 171 U.S. 578 (1898).

157. Texaco, Inc. v. Dagher, 547 U.S. 1 (2006).

158. Bd. of Trade v. United States, 246 U.S. 231 (1918).

159. Appalachian Coals v. United States, 288 U.S. 344 (1933).

160. United States v. Socony, 310 U.S. 150 (1940).

161. See generally Carstensen, supra note 8 .

162. Id. at $1-2$.

163. Id. at 5. The Board of Trade, like all commodity and stock exchanges, creates a "public" market in the same way that British private schools are "public schools." Anyone can trade (enroll) so long as they are admitted or, in the case of trading, employ an agent who is a participant in the joint enterprise. 
services to facilitate its members' transactions. ${ }^{164}$ In order to be an efficient and reliable market maker in commodities, the Board had to avoid the risk that its members would manipulate prices either on or off the Board in ways that would affect the integrity of the private trading market that it supported. ${ }^{165}$ As with any joint venture, there is a concern for the risk of strategic conduct inconsistent with the collective interest of the venture. ${ }^{166}$ If the participants or their customers came to regard the Board's prices as manipulated and misleading, they would and could take their business elsewhere. One risk came from grain "to arrive," which is grain purchased directly from a rural elevator for future delivery in Chicago in reliance on the Board's grading, weighing, and inspection. ${ }^{167}$ The key concern was that integrated buyers ${ }^{168}$ were able to bid for such grain while the Board was not open by engaging in "after-hours trading." 169

During the day, rural elevators could seek competing "to arrive" bids for their grain through their agents on the Board. ${ }^{170}$ The agent could match or beat such an offer only if it had a counter-party willing and able to buy the grain. ${ }^{171}$ Moreover, during the day, the agent for the rural elevator had to charge the commission rate set by the Board for any transaction on the exchange while the integrated buyer would pay directly the full amount of its bid. ${ }^{172}$ Hence, even during the day, sales through the exchange could be at a competitive disadvantage if the transaction costs of direct purchases were less than the commission rate required of agents. ${ }^{173}$ An additional implication of forcing transactions into the time when the exchange was open was that prices offered by any "to arrive" bidder would be immediately revealed. ${ }^{174}$ This, in turn, provided important information about future demand to all traders in the market and so avoided opportunistic risks in the related markets for physical grain already present in Chicago and for futures contracts.

By using the "to arrive" mechanism at night, the integrated firms could conceal their demand for grain, meaning that if they needed a large supply, they could bid at night without immediately revealing that demand to other traders. ${ }^{175}$ In addition, they could offer a lower price for grain to arrive during the day on the Board, followed by higher overnight offers,

164. Id. at $22-25$.

165. Id. at $25-31$.

166. Id. at 23.

167. Id. at $18-22$.

168. See id. at 28. These were firms that traded on the board and operated major grain elevators in Chicago that provided the public warehousing of grain, which was used to settle some futures contracts, as well as private elevators, through which they conducted a large scale business in grain. These firms were often also integrated by ownership with rural elevators that bought grain directly in the country. Id.

169. Id. at $26-28$.

170. Bd. of Trade v. United States, 246 U.S. 231, 236-37 (1918); Carstensen, supra note 8 , at 30 .

171. Carstensen, supra note 8 , at 47.

172. Id. at $50-52$.

173. Id. at 30 .

174. $I d$.

175. Id. at 27. 
followed again by lower prices during the day. ${ }^{176}$ This price manipulation could induce sales at less than the fully competitive price for such grain given the resulting uncertainty about future prices. ${ }^{177}$

The integrated firms also could and did use the ability to specify the destination of the grain within Chicago to keep rural elevators from arbitraging the bid by having another elevator respond to the bid. ${ }^{178}$ This facilitated price discrimination among rural elevators and allowed the bidders to favor their own and associated rural elevators. ${ }^{179}$ They also used selective bidding to attempt to exclude farmer cooperatives and independent elevators in the rural markets. ${ }^{180}$

A committee of the Board consisting of representatives of all its stakeholders, including agents of sellers, buyers, and integrated elevators, drafted the "to arrive" rule. It required only that a buyer wishing to buy at night come to the Board and make a public bid for the grain it wanted at the price it was willing to pay. ${ }^{181}$ If the buyer did not get the gain it desired, it or any other buyer was free to bid at night at that price. ${ }^{182}$ The one constraint on the price was that it had to be the net of the commission that a rural elevator's agent would have collected if the sale were on the exchange. ${ }^{183}$ Thus, at night, prices would be about one-half cent per bushel less than the price the rural elevator could get during the day on direct "to arrive" sales. ${ }^{184}$

The result of this restraint was that trading in grain "to arrive" moved into the time period when the exchange was open. ${ }^{185}$ Direct buyers during that period could send bids by telegram or phone to rural elevators, and the elevators could contact their agents on the floor of the Board to see if they could get a better price. ${ }^{186}$ Since during this time period the direct buyer's price was not reduced by any commission, while an exchange transaction required that the seller's agent collect a fixed commission, the direct buyers may have had a minor pricing advantage to the extent that the fixed commission exceeded the actual transaction cost. ${ }^{187}$

A review of all available documents relating to the call rule disclosed no convincing evidence that the rule functioned to preserve a commission

176. Id.

177. Id. at 28 .

178. $I d$.

179. Id.

180. Id. A farmer cooperative elevator usually had a larger capacity than an affiliate of the integrated chains; because its owners gained directly from higher net prices, the managers had every incentive to get the best net price for grain. Thus, these organizations represented a vertical integration through a potential bottleneck that could otherwise exploit monopsony power in a period when there was very high transportation cost and so very limited choice of buyers for farmers. See id. at 29.

181. Bd. of Trade v. United States, 246 U.S. 231, 235-37 (1918).

182. Id. at 236-37; Carstensen, supra note 8, at 33 .

183. Carstensen, supra note 8, at 33.

184. Id.

185. Bd. of Trade, 246 U.S. at 240.

186. Id. at 236-37.

187. Carstensen, supra note 8 , at 33 . 
price fix or to allocate business to agents on the exchange. ${ }^{188}$ Indeed, the fact that the direct buyers were free to bid any price they wanted during the day creates a strong presumption that the rule was unrelated to any artificial market allocation or commission fixing effort. Instead, its function was to deal with a problem of strategic conduct by one class of participants and so preserve the efficiency and integrity of the Board's market facilitating function. ${ }^{189}$

The foregoing factual-functional analysis was in fact central to the argument for the Board in its brief to the Supreme Court. ${ }^{190}$ The Government's response was simply to reiterate that the parties had agreed on prices for the purchase of grain at night. ${ }^{191}$ The great statement of the "rule of reason" by Justice Brandeis in his opinion is entirely consistent with the ancillary restraint model that Justice Taft had propounded in Addyston Pipe. When a restraint is ancillary, it "merely regulates" competition; while a naked restraint, "suppress[es] or even destroy[s] competition." 192 Indeed, very similar language can be found in Joint-Traffic as well as in the underlying review at the Department of Justice that had originally concluded that no suit was warranted. ${ }^{193}$ That Justice Brandeis put a broader interpretation on the standard and in fact understood it in terms of Justice White's dissent in Trans-Missouri is evident from his dissent in American Column \& Lumber. ${ }^{194}$ Indeed, Justice Brandeis's advocacy of resale price maintenance also demonstrates that his own views were that all restraints of competition should be subject to an open-ended evaluation of their social-economic merits. ${ }^{195}$

Appalachian Coals ${ }^{196}$ is a different case factually and functionally from Chicago Board of Trade. The soft coal industry had peaked in production during World War I and then went into steady decline. ${ }^{197}$ In part, this was the result of switches by consumers to other sources of energy, espe-

188. Id. at 41 . The only counter evidence is one document from a grain trader suggesting a market allocation agreement among various Board of Trade stakeholders, including fixing excessive commission rates. However, efforts to verify these claims proved unavailing. Id.

189. Id. at 36 . One other fact worth passing reference is that the integrated buyers could bid at night at any price they wanted, provided that they did not use the Board of Trade's Chicago weighing, grading, and inspection services. Thus, buyers did occasionally use Peoria, Waukegan, or Indianapolis as the place for delivery when they had an unexpected need to acquire grain at a higher price overnight. See id. at 36.

190. Id. at 53-55 (examining the argument set forth in Board of Trade's brief).

191. Id. at 55-56 (summarizing the Government's brief in reply).

192. Bd. of Trade, 246 U.S. at 238.

193. United States v. Joint-Traffic Ass'n, 171 U.S. 505, 577 (1898); Carstensen, supra note 8 , at 64 (citing the internal Justice Department memoranda on the case).

194. Am. Column \& Lumber Co. v. United States, 257 U.S. 377, 415 (Brandeis, J., dissenting).

195. McCraw, supra note 135 , at $46-52$.

196. Appalachian Coals, Inc. v. United States, 288 U.S. 344, 356 (1933).

197. For histories of the industry, see generally Waldo E. Fisher \& Charles M. James, Minimum Price fixing in the Bituminous Coal Industry (1955); James P. Johnson, The Polttics of Soft Coal: The BItuminous Industry from World War I Through the New Deal (1979); Glen Lawhorn Parker, The Coal Industry: A STUdy in Social CONTROl (1940). 
cially fuel oil and natural gas. ${ }^{198}$ In addition, so long as the distribution of coal involved a great many local retailers, the entry barriers into the mining of coal were very low. ${ }^{199}$ As a result, supply regularly exceeded demand in the 1920s, and that imbalance got worse with the onset of the Depression. ${ }^{200}$ For many years, coal producers and union leaders had advocated various kinds of production controls that sought to raise prices and, on the union side, ensure better wages and working conditions. ${ }^{201}$ The underlying economic error in this approach is that increased prices would only hasten the switch away from the use of coal for many purposes. $^{202}$ Moreover, so long as entry to producing coal remained open and easy, any price increase would be likely to call forth new supplies. ${ }^{203}$

The historical record strongly suggests that the intent of Appalachian Coals organizers was to create a cartel that would set prices and allocate production of coal in Appalachia in conjunction with regional cartels in other coal producing parts of the country. ${ }^{204}$ Moreover, it is very likely that the trial court understood the arrangement as having that kind of a "direct" effect on competition. ${ }^{205}$ But the Supreme Court re-framed the case. It converted the cartel into a joint venture to market coal more efficiently. ${ }^{206}$

Chief Justice Charles Evans Hughes, who had written the Dr. Miles decision during his earlier service on the Court, wrote the decision. ${ }^{207}$ Given his Dr. Miles opinion, Justice Hughes had a grasp of the functional analysis that had guided antitrust law's standards governing restraints of trade. He also faced a political problem. At the time the case came to the Court, there was wide-spread agreement in the political and economic community that "excessive competition" had created the Great Depression. ${ }^{208}$ If the Court had upheld the lower court's condemnation of the Appalachian Coals agreement, this might have lead to repeal of the antitrust laws altogether. ${ }^{209}$ So, Justice Hughes rewrote the Appalachian story. He converted a project to stabilize price and output by use of regional cartels into a joint venture to market coal more efficiently. The opinion stressed the inefficient and chaotic nature of the process by which small scale coal mines marketed their coal. ${ }^{210}$ For example, mine owners

198. FISHER \& JAMES, supra note 197 , at 10.

199. Id. at $4-5,437-39$.

200. Id. at 13-19.

201. Fisher \& JAMES, supra note 197, at 3-19; JohnSON, supra note 197, at 1-165; PARKER, supra note 197, at 85-104.

202. See Fisher \& JAMES, supra note 197, at 406.

203. Id. at 407.

204. See PARKer, supra note 197 , at 163.

205. John Uelman, Appalachian Coals v. United States 13 (unpublished seminar paper on file with the author).

206. See infra text accompanying notes 210-13.

207. See Appalachian Coals, Inc. v. United States, 288 U.S. 344, 356 (1933); Dr. Miles Med. Co. v. John D. Park \& Sons Co., 220 U.S. 373, 376 (1911).

208. See generally Temp. Nat'l Econ. Comm., Monograph No. 32, Economic Stan. dards of Government Price Control 32 (1941).

209. GAVIL, ET AL., supra note 4, at 95-97.

210. Appalachian Coals, 288 U.S. at 356-359. 
often empowered multiple brokers to sell the same carload of coal already destined for the same location. ${ }^{211}$ Thus, the coal wound up competing with itself as well as with other suppliers. ${ }^{212}$ Clearly, there was a strong case for some kind of a joint venture that would have a sufficient volume of coal on a consistent basis, creating a more efficient marketing system. By making Appalachian Coals into an effort to improve efficiency in marketing Justice Hughes provided an ancillary restraint justification for collective price setting and allocation of production. ${ }^{213}$ Essentially, the parties had to agree on how to price their production and how to determine the markets to which it would be sent. In modern terms, the result is somewhere between Dagher's total integration of selected economic activities ${ }^{214}$ and the joint venture to market pooled copyrights upheld in the $B M I$ case. ${ }^{215}$

The Government's failure to dispute the arguments and evidence of the coal companies with respect to the problems of marketing coal greatly aided the Court's retelling of the story. ${ }^{216}$ Indeed, the lower court judges identified this issue and, through their questioning, found that much smaller combinations of coal companies could achieve the volume necessary to create an efficient and rational marketing system..$^{217}$ In addition, Appalachian Coals had not yet come into existence. ${ }^{218}$ There was an agreement but no actual conduct. Hence, the Government was in one sense speculating that the result would be a cartel and not a legitimate joint venture. ${ }^{219}$

Given the context of the case, the Court's analysis is consistent with the view that there was a plausible argument that the venture was a legitimate effort to create an efficient and effective method of marketing coal. As such, the only real test was to see what it did in practice. The effect of the opinion, therefore, was to invite continued scrutiny of the venture. Moreover, that scrutiny would take place against a framework that made a cartelistic use of the venture unlawful.

In 1933, it would have been impossible for a regional soft coal cartel to exercise any real market power. ${ }^{220}$ The barriers to entry were too low and the capacity of other mines to ship into any region with higher prices was well known. 221 Hence, viewed realistically, the industrial context of

211. Id. at 363 .

212. Id.

213. See id. at 372.

214. See generally Texaco Inc. v. Dagher, 547 U.S. 1 (2006).

215. Broadcast Music, Inc. v.CBS, 441 U.S. 1, 23-24 (1979).

216. Uelman, supra note 205 , at $13-14$.

217. Id. at 18 .

218. FisHer \& JAMEs, supra note 197, at 21.

219. Uelman, supra note 205 , at $13-15$ (stating that the Government had to speculate about the effects of the agreement, which really required industry wide collusion and not merely a sales agency in one region).

220. FISHER \& JAMES, supra note 197, 406-08; PARKER, supra note 197, 170-174; TEMP. Nat'l ECON. COMm., MONOGRaph No. 21, COMPETITION aNd MONOPOly IN AMERICAN INDUSTRY 24-26 (1940).

221. See Temp. Nat'l Econ. Comm., Monograph No. 21, supra note 220 at 24-26. 
soft coal doomed Appalachian Coals from the outset if its purpose was to create higher prices by restricting output.

Even as the case was being remanded, in March of 1933, Congress was adopting the National Recovery Act (NRA), which expressly authorized trade organizations to engage in price fixing and market allocation, exempt from antitrust law. ${ }^{222}$ By September of 1933, the soft coal industry had established a trade code that had as an express goal raising prices and reducing output. ${ }^{223}$ Of course, this would hasten the conversion to other sources of energy and so would generally reduce demand. Appalachian Coals seems to have had a role in attempting to administer these restraints in its area. 224 The project floundered even before the Supreme Court overturned the NRA as a result of easy entry and regional cost differences that frustrated any effort to achieve price and output control. ${ }^{225}$

With the end of the NRA, parts of the industry assisted vigorously by the United Mine Workers, turned to Congress for direct statutory authorization for their cartel. ${ }^{226}$ They got it in the Guffey Coal Act, which created a regulatory agency that was to set prices and regulate wages as well as working conditions. ${ }^{227}$ But this statute was itself struck down because it included controls over the wages to be paid coal miners. ${ }^{228}$ This, the Court declared, was strictly a matter of "intra-state commerce" and so the statute was unconstitutional. ${ }^{229}$

Congress tried again; this time the statute only authorized price fixing for coal to be sold in interstate commerce. ${ }^{230}$ An agency, later replaced by an office in the Department of Interior, ${ }^{231}$ was to review and approve prices set by regional organizations. ${ }^{232}$ Moreover, the statute imposed an onerous tax on any coal mine that either refused to participate in or honor the prices set by the regional groups. ${ }^{233}$ Since each region sold coal in a variety of retail markets and the statute required that all prices

222. National Industrial Recovery Act, ch. 90, 48 Stat. 195 (1933) (formerly codified at 15 U.S.C. \& 703).

223. PARKer, supra note $197,110-14$ (the coal code was initially approved on September 18, 1933 and become operational on October 2, 1933).

224. Id. at 163-74. Parker suggests that it played something of a role as a sales agency directly marketing the production of its members, but its primary role in the $1930 \mathrm{~s}$ was to act as the local coordinating agency first for the NRA code and later for the Guffey-Vinson Act, but it was inactive during the period of the Coal Conservation Act of 1935 because that Act did not provide an antitrust exemption. Id.

225. JOHNSON, supra note 197, 217-24.

226. PARKER, supra note $197,142-49$.

227. JoHnson, supra note 197, 220-26.

228. Carter v. Carter Coal Co., 298 U.S. 242, 309-10 (1936). The Carter decision relied on the E.C. Knight case to define a very narrow scope for interstate commerce. Id. at 300 01 .

229. Id. at 307.

230. JoHNSON, supra note $197,228-36$.

231. Ralph Hillis Baker, The National Brtuminous Coal Commission: Administration of THE BItUminous Coal ACt 1937-1941 120 (1941).

232. JOHNSON, supra note 197, at 231.

233. Id. 
be sufficiently high to allow recovery of all costs, the consequence was a regulatory nightmare. ${ }^{234}$ Different regions tried to harmonize prices to ensure that no one got a competitive advantage, but consensus was not readily achieved. ${ }^{235}$ Fortunately the statute had a "sunset" clause and it terminated shortly after the on-set of World War II. ${ }^{236}$

After the war, the coal industry experienced a continued transformation of its structure as retail coal sales largely disappeared with the conversion of most residential and retail businesses to fuel oil or nature gas to power their furnaces. ${ }^{237}$ Without retail coal dealers willing to buy coal from any number of sources, producers had to achieve substantial and reliable volumes in order to satisfy the demands of electric generators and massive industrial heating plants. ${ }^{238}$ Thus, with significant political and organizational push from the union that worked vigorously to eliminate small mines, the industry became sufficiently oligopolistic that it no longer needed or wanted government regulation of its prices. ${ }^{239}$

Thus, the history of the soft coal industry from 1920 to 1940 is one of a fruitless search for an effective cartel in which Appalachian Coals is a minor event that contributed little or nothing to achieving that goal. But the Supreme Court decision in that case needs to be read in the context of both that history and the carefully chosen analysis invoked by Chief Justice Hughes. Unfortunately, the obvious fact that the promoters intended a cartel combined with the Court's ambiguous language in Appalachian Coals along and its open-ended language in Chicago Board of Trade $^{240}$ has created a broad "good things" justification for horizontal restraints. ${ }^{241}$ This view misstates the factual-functional doctrinal analysis, which is explicit in the decision, and ignores the history of the venture itself.

The framing of this earlier period requires attention finally to the Socony case, decided in $1940 .{ }^{242}$ There are a number of aspects to this his-

234. FISHER \& JAMES, supra note 197, 50-64; JOHNSON, supra note 197, 232-38.

235. FISHER \& JAMES, supra note 197, at 190.

236. JoHNSON, supra note 197 , at 236.

237. FISHER \& JAMES, supra note 197, at 5-7. However, even in 1950 there were nearly 9,500 mines in 28 states. Id. at 5 .

238. The historic record is of sustained decline in use of coal for home heating and transportation (coal fired steam engines on railroads and in ships). See RICHARD Bon. skowski et al., Energy Info. Admin., Coal Production in the United States-An HISTORICAL OVERVIEW 1 (2006), available at http://www.eia.doe.gov/cneaf/coal/page/ coal_production_review.pdf. For example, there is currently no home consumption of coal reported by the Energy Information Administration. See ENERgy INFo. Admin., U.S. CoAl Consumption By End-Use Sector (2009), available at http://www.eia.doe.gov/ cneaf/coal/quarterly/html/t27p01p1.html.

239. See United Mine Workers of Am. v. Pennington, 381 U.S. 657, 660-62 (1965) (starting in early 1950s, the union undertook to drive small, non-union operators from the business).

240. Bd. of Trade v. United States, 246 U.S. 237, 242 (1918).

241. See, e.g., Cal. Dental Ass'n v. FTC, 526 U.S. 756, 771-73 (1999); State Oil Co. v. Khan, 522 U.S. 3, 14-18 (1997); see also United States v. Brown Univ., 5 F.3d 658 (3d Cir. 1993).

242. Socony-Vacuum Oil Co. v. United States, 310 U.S. 150 (1940). 
tory that need not be explored here, although it merits specific note that Department of the Interior, which was the administrator of the effort to create a publicly run coal cartel, was also the proponent of the private "dancing partner" agreement that was central to the case. ${ }^{243}$ To create and maintain higher wholesale prices for gasoline, each major integrated refiner agreed to buy surplus gas from its assigned "dancing partner." This "dancing partner" was an independent refiner whose excess production, sold in the publicly reported wholesale market, would depress prices. $^{244}$

Socony expressly adopted the per se rule against price fixing. The Socony opinion reviews early case law and concludes with the declaration that "for over forty years this Court has consistently and without deviation adhered to the principle that price-fixing agreements are unlawful per se under that Sherman Act."245 Yet this forty-year period encompasses both Chicago Board of Trade and Appalachian Coals, in which price fixing was expressly allowed.

The Socony opinion explained Appalachian Coals as an "agency ... to establish standard classifications and sell the coal of its principals at the best prices obtainable. ... The agency was to ... make the sale of coal more economical."246 Similarly, the Board of Trade case is characterized as one involving the "creation of a public market for grains" in the "to arrive" class. ${ }^{247}$ In contrast, echoing the language of Trans-Missouri and Joint-Traffic, the Socony defendants are characterized as engaging in "buying programs of distress gasoline which had as their direct purpose and aim the raising and maintenance of spot market prices." 248

The forty years of per se illegality for price fixing is logical only if it applies to naked (direct) restraints. Where the restraint is at least arguably ancillary, meaning a reasonably necessary regulation of the parties' relationship that serves some inherent need of the venture or controls risks of strategic conduct, then the courts can and should look at the justification. In contrast, when the restraint, as in Socony, is not the product of a joint productive venture among the parties, then it is a naked re-

243. Daniel A. Crane, The Story of United States v. Socony-Vacuum: Hot Oil and Antitrust in the Two New Deals in ANTITRUSt Stories 95-98 (Eleanor M. Fox \& Daniel A. Crane eds., 2007).

244. There is no doubt that the "dancing partner" arrangement was both intended to and did have the effect of raising and stabilizing prices. See generally D. Bruce Johnsen, Property Rights to Cartel Rents: The Socony-Vacuum Story, 34 J.L. \& Econ. 177, 179 (1991). The strongest defense was that Harold Ickes, Secretary of the Interior, had ordered the companies to raise prices and that they were acting under government compulsion. See Crane, supra note 134, at 97 . Interestingly, and comparable to the coal case, after the NRA was overturned, Congress adopted the Connally Hot Oil Act, 15 U.S.C. 715 (2000), which effectively conferred on the Texas Railroad Commission the ability to regulate the production of oil. This state managed cartel seems to have been more effective than the coal cartel. See Laurie E. Jasinski, ConNally Hot OIl Act of 1935 (2008), available at http://www.tshaonline.org/handbook/online/articles/CC/mlc3.html.

245. Socony, 310 U.S. at 218.

246. Id. at 214-15.

247. Id. at 217.

248. See id. at 216 (emphasis added). 
straint of competition and so should be absolutely illegal.249 This consistent thread of decision as noted runs back to the first Supreme Court decisions. The exceptional cases, both before and after Standard Oil announced the rule of reason, involved horizontal restraints where there was a plausible ancillary argument for the conduct. ${ }^{250}$

It should also be noted that at the time of decision in Socony, there had been no academic or legal discussion of the ancillary restraint concept for many years. Thus, while the foundation cases consistently apply the distinction between naked and ancillary restraints, the lack of clearly defined legal terminology obscured this doctrinal consistency. Indeed, the absolutist language of the Socony decision may suggest that any agreement among competitors was illegal, but that strong language needs to be balanced against the Court's simultaneous acceptance of the legitimacy of the outcome in both Chicago Board of Trade and Appalachian Coals.

The reasons for the loss of this doctrinal consistency are readily apparent when one reviews the secondary literature about antitrust and the cases used as doctrinal guideposts. Essentially the Peckham-Taft model of functional analysis was lost. The language of Chicago Board of Trade divorced from its context, became the touchstone of legal analysis. Whether restraint is one that "suppresses competition" and is, therefore, unreasonable or "merely regulates" it and so is reasonable invites an open-ended consequentialist view of the analytic process. ${ }^{251}$

Only in the late 1950s did Robert Bork begin the reintroduction of the Addyston Pipe analysis into the examination of restraints of trade. ${ }^{252} \mathrm{Un}$ fortunately for doctrinal logic, Bork wanted to prove that most prior Supreme Court decisions, except those condemning cartels, were irrational and inefficient. ${ }^{253}$ Hence, he used ancillary restraint analysis as a club to beat the Court rather than as a tool to seek out the consistency in the decisions. To his credit he imagined legitimate business justifications for a number of restraints that the courts had condemned. He also imagined anticompetitive explanations for some restraints upheld by the Court, such as Chicago Board of Trade. ${ }^{254}$ When he did not do is look critically at the factual analysis that the courts had employed to see if there was a

249. This standard applies except when there is express or implied authorization for such a restraint. See generally Peter Carstensen \& Bette Roth, The Per Se Legality of Some Naked Restraints: A (Re)Conceptualization of the Antitrust Analysis of Cartelistic Organizations, 45 ANTITRust Bull. 349 (2000).

250. See, e.g., Dr. Miles Med. Co. v. John D. Park \& Sons Co., 220 U.S. 373 (1911). Dr. Miles is consistent with this doctrinal framework. As discussed supra, it was an application of the rule of reason to a set of facts where the party seeking to justify the restraint had in fact failed to offer a legitimate justification for the restraint.

251. See, e.g., Cal. Dental Ass'n v. FTC, 526 U.S. 756 (1999); State Oil Co. v. Khan, 522 U.S. 3 (1997); Nat'l Ass'n of Window Glass Mfrs. v. United States, 263 U.S. 403 (1923); see also United States v. Brown Univ., 5 F.3d 658 (3d Cir. 1993).

252. Robert H. Bork, Ancillary Restraints and the Sherman Act, 15 A.B.A. ANTITrust LAW SEC. 211 (1959).

253. See generally BoRK, supra note 141.

254. Id. 
plausible naked restraint hypothesis or whether there were, actually, facts that supported his contrary theory.

It seems likely that where the justices felt that specific prior decisions were plausible, they would be reluctant to embrace a theory of antitrust that its author said called into question so many of their prior decisions. The result is that as economic analysis has overtaken antitrust law, it has come not with a sharp functional edge, but rather in the consequentialist mode of the early White dissents and relies very much on the open language of Chicago Board of Trade rather than the focused language of Addyston Pipe.

\section{CONCLUSION}

The broad historical thesis argued for here is that there is a consistency to the prevailing analysis of restraints of trade in the foundation cases for antitrust law. The central issue was whether or not the specific restraint is ancillary to, a functional incident of, some legitimate joint venture or transaction involving the parties to that restraint. When the facts support such a conclusion, the courts need to look carefully at the question of whether the restraint is excessive, assuming it in fact has a legitimate justification. On the other hand, when a restraint does nothing but restrict competition among its participants to create, allocate and exploit market power, then antitrust law condemned such direct restraints regardless of excuse or justification. Sadly, this doctrinal clarity has been obscured and even lost in the repeated efforts to translate it for application in new and different cases.

Can we restore the deeper meaning of antitrust doctrinal statements when connected to the factual analysis that supported them? It would be a herculean task, given the need to educate (or re-educate) any number of judges, lawyers and law professors who have become lost in their efforts to translate the doctrinal statements of antitrust law into contemporary decisional frameworks. The Leegin case is the most recent sad example of a court ignoring the available insights of the past because of a misreading of the analysis and doctrinal rationale of $D r$. Miles. Perhaps, the best we can hope for is that periodic forays into the history of the leading cases will give courts pause as they try to appropriate language and doctrinal categories divorced from their factual contexts. 